\title{
THE POSITION OF THE GUARANTOR IN RECONCILIATION ON THE BANKRUPTCY ACT ACCORDING TO THE LAW OF BANKRUPTCY IN INDONESIA
}

\author{
Siti Mahmudah, Siti Malikhatun Badriyah, Bagus Rahmanda \\ Faculty of Law, Diponegoro University, Indonesia \\ sitimahmudah.fhundip@gmail.com
}

\begin{abstract}
The existence of the guarantor in the world of business is widely known and required in the business world. Guarantor is stipulated in the agreement of guarantor which states that the Guarantor will pay the debt of debtor to its creditor if the debtor do not pay. The debt fulfillment of debtor to creditor can be done through the Bankruptcy Act which ended with reconciliation. The purpose of this research is to examine the position of the Guarantor in reconciliation on the Bankruptcy Act according to the Law of Bankruptcy in Indonesia, with the problem of how the position of the guarantor against debt fulfillment of debtor which ended with reconciliation in bankruptcy in Indonesia, and as a result of the approval of reconciliation in the bankruptcy of the submission of the claim the statement of bankrupt guarantor. The approach used in this research is the normative juridical, with a descriptive specifications analysis with the type of secondary data through the study of primary, secondary and tertiary legal material library which is then analyzed by qualitative research.

The reconciliation that passed in bankruptcy does not always result to receivables of the creditors being paid for. Based on the provisions of Article 165 paragraph (1) Of Law No. 37 Of 2004 on Bankruptcy and Suspension of Obligation for Payment of Debts, Guarantor will still be obligated to pay off the debtor's debts that are borne which can cause the guarantor privileged as the debtor so it can be filed for bankruptcy if fulfilled the provisions of Article 2 paragraph (1) Of Law No. 37 Of 2004 on Bankruptcy and Suspension of Obligation for Payment of Debts.
\end{abstract}

Key Words: Guarantor, Bankruptcy, Reconciliation.

\section{Introduction}

Various forms of cooperation is known in the community. Various forms of the cooperation can be grouped in a cooperation or purposed at social and economical. The purpose of cooperation is to gain economically. This advantage is obtained by running the company namely an act that's done to gain profit.

One of the conditions that must be fulfilled in the running of the company is the requirements regarding the legality of the form of the company. There are many forms of company, it can based on the number of the owner of the differentiated in individual company owned by one person and the company partnership, which is a cooperation that is owned by more than one person, because the basis of its establishment is the agreement.

The company in the form of the partnership differentiated in the company is a legal person and that is not legal person. The company non-legal person consists of the Civil Partnership set 
forth in the Civil Code (Civil Code), Firm (General Partnership), and Limited Partnership regulated in Commercial Code.

The benefits of which is the purpose of running a good company that uses a form of individual company, Civil Partnership, General Partnership, Limited Partnership will be more along with the development of the company. Capital is a crucial factor for developing company.

The fulfillment of the needs of the capital can be filled internally and externally. The fulfillment of the needs of internal capital is derived from the corresponding entrepreneurs, while fulfilling the needs of external capital is the fulfillment that comes from outside parties, as example is the financial institutions.

Financial institutions that can be used in fulfillment of the capital can be differentiated into financial institutions banks and non-bank. Financing Institution is one of the non-bank financial institutions that can be used to fulfill the needs of the capital.

In fulfilling the needs of external capital is done by closing an agreement that resulted to the party who need furthermore capital as the debtor, while those who gave the capital are called the creditors. According to Article 1 number 6 of Law No. 37 of 2004 on Bankruptcy and Suspension of Obligation for Payment of Debts, debtor are those who have a debt because of the agreement or an act, paying off the debt that can be billed through the courts, in some cases there are also creditors that is the one who has the receivables because of the agreement or the laws that paying off the debt that can be billed through the courts.

In the agreement, occasionally the creditor ask the debtor for customise guarantees, which can be a material guarantee or personal guarantee to fulfill an obligation to the creditor if later on the day of the debtor does not fulfill its obligation (pay debt), while the general guarantee is a guarantee that is arranged in Article 1131 and Article 1132 Civil Code.

According to the provisions of Article 1131 Civil Code, all assets of the debtor, both to move or not to move, both new and existing in the later day, be liable for any individual partnership, and while according to the provisions of Article 1132 Civil Code, the assets becomes collateral for all those who debt to him, sales revenue of the objects are divided according to how big or small each receivables, except when in between the creditor had no valid reasons to take precedence.

In terms of these articles can be realized among others through bankruptcy institutions in the fulfillment of the debt. According to the provisions of Article 1 number 1 Of Law No. 37 Of 2004 on Bankruptcy and Suspension of Obligation for Payment of Debts, what is meant by 
bankruptcy is the common consfication of all the assets of debtor bankrupt that self and the fulfillment done by curator under the supervision of judges supervisors as set forth in this law.

Based on the provisions of Article 1 number 1, then bankruptcy is the freezing of the civil rights bankrupt debtor to manage their own assets. All assets of the bankrupt debtor in general confiscation possessed by the curator under the supervision of judges supervisors. ${ }^{1}$

One of the task of a curator is to do the fitting of receivables (verification). According to the provisions of Article 178 paragraph (1) Of Law No. 37 Of 2004, if in fitting receivables meeting not offered reconciliation proposal by the debtor or reconciliation proposal was not accepted by the meeting or the legalization of reconciliation was rejected based on the decision of the commercial court that has acquired the force of law that remain, then by the law of the bankruptcy estate in the insolvent situation, which for the next done liquidated. The results of the liquidated by curator distributed to the creditors in order to debtor's debt that has been recognized in the process of matching receivables. The distribution was conducted in accordance with the sequence of the level of each receivable that has been determined by the law. ${ }^{2}$

Thus the statement bankrupt against the debtor by commercial court judges who caused a general consfication on all assets of the bankrupt debtor that for the next much done by the curator does not always result in the debtor bankrupt in the condition of the insolvent situation, because the debtor still given the right to offer reconciliation as it is regulated in Article 144 Of Law No. 37 Of 2004 and if reconciliation was passed by judges supervisors and has acquired the force of law remains then bankruptcy ended as it is regulated in Article 166 Of Law No. 37 Of 2004.

\section{Problems}

Based on the description above, it is interesting to do further studies in a research on "Position of the Guarantor in Reconciliation on the Bankruptcy Act According to the Law of Bankruptcy in Indonesia" with issues:

1. How the position of the guarantor against debtor's debt fulfillment which ended with reconciliation in bankruptcy in Indonesia?

2. Whether with the legalization of reconciliation that followed with the end of debtor bankruptcy is the base of the rights of filing bankrupt declaration of the guarantor to commercial court judges?

\footnotetext{
${ }^{1}$ Kartini Mulyadi dan Gunawan Widjaja, Pedoman Menangani Perkara Kepailitan, (Jakarta : Rajawali Pers, 2005), hal. 212.

${ }^{2}$ Sutan Remy Sjahdeini, Hukum Kepailitan Memahami Undang-Undang No. 37 Tahun 2004 Tentang Kepailitan, (Jakarta : PT Pustaka Utama Grafiti, 2010), hal. 279.
} 


\section{Research Methods}

This research outline can be grouped in the doctrinal legal research which researches on the law that is originated and developed on the basis of the doctrine that embraced by the conceptual and or the developer. This research using the methods of the study of the law which conceptualized as a rule of law according to the doctrine of the positivism flow in the science of law often referred to as a research method that normative. ${ }^{3}$ The normative legal research is a type of research that is often done in the activities of the development of the science of the law in the west usually also called dogmatics law (Rechtdogmatiek). ${ }^{4}$ Thus the approach method used in this research is the normative juridical approach because this research wants to find the law for an inconcreto case which is an effort to find the appropriate law to be applied inconcreto to resolve a certain case and where the sound of the regulation found. ${ }^{5}$

The specifications in this research is a descriptive analytical. This means that a descriptive paints the research object based on the fact that there is, conducted systematically, chronological order based on the rules of the scientific. Analytical means describes the research object associated with the theories of existing law and/or legislation related to the object that is examined. This research is intended to find out about the position of the Guarantor in reconciliation on the Bankruptcy Act according to the Law of Bankruptcy In Indonesia, which then continued to analyze it from the aspect of the law by using the rules of applicable law.

The type of data in this research is secondary data, in the form of legal materials. The material of the law is the source of the data that is required in the implementation of a research. Legal materials include primary legal materials, secondary legal material and tertiary legal materials. In this research it uses the primary legal materials and secondary legal materials. Secondary legal materials data is strengthened by the results of the interview that is more inventarized, which began with the identifying and followed by the election of the legal materials in a systematic and logical way, then analyzed in qualitative research using logic deductive and assisted with the approach of legislation, so that it can be explained about the position of the guarantor in reconciliation on the Bankruptcy Act according to the Law of Bankruptcy in Indonesia.

\footnotetext{
${ }^{3}$ Sutandyo Wignjosoebroto, Hukum: Paradigma, Metode dan Dinamika Masalahnya, (Jakarta : Elsam \& Huma, 2003), hal. 147 .

${ }^{4}$ Bernard Arief Sidharta, Penelitian Hukum Normatif: Analisis Penelitian Filosofi dan Dogmatikal, dalam Sulistyowati Irianto dan Sidharta (editor), Metode Penelitian Hukum, Konstelasi dan Refleksi, (Jakarta : Yayasan Obor Indonesia, 2009), hal 142.

${ }^{5}$ Ronny Hanitijo Soemitro, Metodologi Peneleitian Hukum dan Juri Metri, (Jakarta : Ghalia Indonesia, 1990), hal. 22.
} 


\section{Discussion}

\section{The Position of the Guarantor Against Debtor's Debt Fulfillment which ended with Reconciliation In Bankruptcy in Indonesia}

In the community especially the business world debtor are not always able or willing to pay the debt. Various ways can be done to resolve the debt of both through the courts and out of court. Debt fulfillment through the courts distinguished in fulfillment through the general courts and special courts. Bankruptcy is a debt fulfillment debtor through special court that is commercial court.

Debt fulfillment through the petition for the declaration of bankruptcy against the debtor to commercial court judges has been regulated since the Dutch Indies era and until now has already experienced some changes. Rules that apply now is Law No. 37 Of 2004 on Bankruptcy and Suspension of Obligation for Payment of Debts further referred to by the UUK-PKPU.

The declaration of bankrupt against the debtor resulted in debtor's assets being in general consfication where the management of them done by the curator for the next distributed to the creditors during the bankruptcy is in the condition of the insolvent situation as the implementation of the provisions of Article 1131 Civil Code that the distribution based on the provisions of Article 1132 Civil Code is based on the basis of Pari Passu Pro Rata Parte, but the declaration of bankrupt against the debtor does not always end up insolvent situation for the debtor, because the debtor has the right to ask the reconciliation proposal.

Reconciliation is one of the chain value in the process of bankruptcy. Reconciliation in the bankruptcy process is often called by the term "akkord" (Dutch), which in English called with the term "Composition". Article 144 of Law No. 37 Of 2004 stated that the bankrupt debtor reserves the right to offer a reconciliation to all the creditors. The purpose of reconciliation in the bankruptcy process is to determine the part of each that will be paid by the bankrupt debtor or curator by liquidate their assets or not. ${ }^{6}$

The stages of the reconciliation process in a bankruptcy are the stage of submitted a reconciliation proposal and the announcement of the reconciliation plan, stage decision making reconciliation, stage of the homologation hearing and cassation against the homologation hearing. Submitted reconciliation proposal and the announcement by the way was placed in the Registrar of the Commercial Court done at the latest 8 (eight) days before the hearing the matching receivables (Article 145 paragraph (1) Law No. 37 of 2004). Reconciliation proposal

${ }^{6}$ Munir Fuady, Hukum Pailit dalam Teori dan Praktek, (Bandung : Citra Aditya Bakti, 2005), hal. 116. 
discussed and taken the decision soon after the hearing of the matching receivables completed (Article 145 paragraph (1) Law No. 37 of 2004). The reconciliation proposal is accepted if it is approved in a creditor meeting by more than $1 / 2$ (one per two) the number of concurrent creditors present at the meeting and whose rights are recognized or temporarily recognized, representing at least 2/3 (two thirds) all recognized or acknowledged receivables recognized from the concurrent creditor or their proxies attending the meeting (Article 151 Law No. 37 of 2004).

When the reconciliation proposal accepted, and before the meeting is closed The Supervisory Judge sets the day of the Commercial Court hearing to ratify the reconciliation (homologation). If the Commercial Court refused to confirm the reconciliation, legal efforts is available for the parties that the objection to the rejection of the appeal to the Supreme Court. Bankruptcy ended after reconciliation ratified and legal approval remains, but if reconciliation was rejected, bankruptcy process immediately into insolvent situation.

Thus the fulfillment of debt through bankruptcy can be ended through a reconciliation in the form of the determination of the distribution of debtor's assets to the creditors as debt fulfillment efforts.

In the world of business the existence of debt and the guarantor has become common. The guarantor including in personal guarantee is a guarantee that cause a direct relationship to the specific individual, arising out of the existence of guarantee agreement. According to the provisions of Article 1820 Civil Code, guarantee is an agreement by which a third party, to the interests of the creditor bind themselves to fulfill the engagement of debtor, whereas the debtor does not fulfill it.

So the guarantor is the person who guarantees the debt repayment of the debtor to its creditors if the debtor could not pay off the debt. Against the guarantor is given special rights as regulated in Article 1831 Civil Code namely the guarantor is not required to pay the creditor, besides if the debtor unaware, while the objects of the owe it must first be seized and sold to pay back the debt owing.

Based on the provisions of Article 1831 Civil Code, it is the duty of the guarantor that appears as a result of the closing of the new guarantee agreement took place after the assets of the debtor is used to pay back the debt owing, if there is not enough assets guarantor used to pay off the debt.

Obligations of the guarantor to ensure debt repayment debtor as set forth in the provisions of Article 1646 Civil Code, debtor is completed through the Bankruptcy Act which 
ended with reconciliation still apply as regulated in Article 165 paragraph (1) Law No. 37 Of 2004 regulating that despite reconciliation, creditors still have rights against the guarantor and fellow debtor.

One of the end of the bankruptcy is the legalization of reconciliation. Bankruptcy ended because reconciliation can pleaded rehabilitation as regulated in Article 215 and 216 Law No. 37 Of 2004. Article 215 Law No. 37 Of 2004 set that after the end of the bankruptcy act as mentioned in Article 166, 202 and 207, then the debtor or heir is entitled to apply for the rehabilitation of the court who had spoken the decision of the statement bankrupt.

Thus the submission of the rehabilitation of the Commercial Court according to the provisions of Article 215 Law No. 37 Of 2004 can only be done toward the end of the bankruptcy when bankruptcy ended with a reconciliation, when ended after the loan paid full, or when bankruptcy is inflicted on property debtor.

Based on the provisions of Article 215 Law No. 37 Of 2004 can be concluded that the end of bankruptcy because of reconciliation is not always the debtor's debt paid for, while the provisions of Article 216 sets that the petition good rehabilitation by debtor and by his heir will not be granted except when there is a letter of application is attached evidence that all the creditors are recognized have payment in satisfying.

Based on the provisions of Article 216 Law No. 37 Of 2004 then granted rehabilitation petition debt does not always debtor paid for, but just a statement from all the creditors who acknowledged that they have payment in satisfying.

Based on the provisions of Article 215 and 216, then reconciliation that confirmed that resulted in the bankruptcy ends does not always result in the debtor's debt paid for. If in the agreement that resulted in the existence of such debt requires the existence of guarantee agreement, the guarantor will still have the obligation to pay the debtor's debt which covered or guaranteed and the guarantor could not demanding the implementation of privilege as regulated in terms of Article 1830 Civil Code, because the assets of the debtor is used to pay the debt of the loan.

\section{Result of the Legalization of Reconciliation in the Bankruptcy Act Against the Submitted Petition for the Declaration of Bankrupt to Guarantor}

The existence of the guarantor in the business world are already widely known and required. According to the provisions of Article 1820 Civil Code, guarantee is the agreement by which a third party, to the interests of the creditor bind themselves to fulfill the engagement of debtor, whereas the debtor does not fulfill it. Thus based on the provisions of Article 1820 Civil 
Code, guarantor was based on an agreement and the agreement is the agreement between the creditor and the giver of the personal guarantee (borg).

Agreement is an act of the law in the field of assets that can be realized in two forms that is the agreement that is done in writing and the agreement that is done orally, where the two forms of the same agreement strength in the meaning of the same position to be performed by the parties. Only a written agreement can easily be used as evidence when the dispute occurs. This can happen because the law applies the basis consensualism agreement that can be deduced in Article 1320 paragraph (1) Civil Code. On the article determined that one of the conditions of the legality of the words of the agreement was agreed between the two sides. This principle is the basis that states that the agreement generally do not held formally, however it is enough only with the agreement on both sides. A deal is the matching between the will and the declaration made by both sides.

The validity of the basis of consensualism resulted in the guarantee agreement can be poured in the form of written or verbal, although according to the provisions of Article 1824 Civil Code, debt guarantor cannot be suspected, because according to the terms of the article does not contain the meaning that the guarantor should be held in writing. It can be held orally. If the guarantee agreement made orally and become a burden for the creditor to prove till where the tuition of the guarantor.

The action of the law both in the form of the agreement that can be poured in writing or verbal cause the relationship of the law,which may be seen in the rights and obligations of the parties that promised. Maximum obligation can respond to a guarantor for debt payment of the entire amount of the loan the debtor plus (if there is a case) with the cost of the case and added with the warning cost of the guarantor and other costs until the time where the guarantor fulfill all of its obligations.

Article 1821 paragraph (1) Civil Code set that there is no guarantee agreement in the absence of a valid legal engagement. Thus the guarantee agreement is an agreement that is accessoir, while the principal agreement is the agreement between the guaranted as the debtor with its creditor, for example the agreement point is credit agreement, a guarantor for bear to fulfill the debt from the debtor of as listed in the agreement of the point namely credit agreement.

In the guarantee agreement it is a usual thing done for legal certainty and the payment of paid for in the guarantee debt agreement with lists clause that the guarantee include: debt, interest, costs, the cost of borrowing and other liabilities that arise caused by anything. Prior to 
fulfill its obligation, guarantor have the right that can be performed in advance the right to demand the sale of debtor's assets first to complete or to pay the debt to the debtor.

Debt fulfillment from the debtor which is covered by the guarantor will occasionally completed through bankruptcy, namely by asking for the debtor declared as bankrupt by the Commercial Court judges in the scope of the Court. In all the region of Indonesia there is only 5 (five) Commercial Court.

After the debtor declared bankrupt there is some judicial actions committed during the bankruptcy process is a matching receivables, reconciliation and homologation, insolvent situation and rehabilitation.

Fitting of Receivables in the Law No. 37 Of 2004 arranged in Article 113 until Article 143. The matching receivables (verification) is one of the important activities in the process of bankruptcy. With the existence of verification can be determined consideration and the sequence of the rights of each of the creditors.

The verification meeting attended by judges Supervisors as the direction of the meeting the scribe as a logger, debtor, in this case must be present and cannot be delegated (Article 121 Law No. 37 Of 2004), all the creditors can present itself or represent its legal counsel (Article 123 Law No. 37 Of 2004) and curator must be present.

The things that were done in the verification meeting was Judge Supervisors read receivables list that recognized while and receivables list that while rebutted by the curator (Article 124 paragraph (1) Law No. 37 Of 2004), every creditor whose name is listed in the list of Receivables can be demanded that the curator gives a description of each receivables and their placement in the list (Article 124 paragraph (2) Law No. 37 Of 2004), curator reserves the right to withdraw the recognition while or tenuous or demanded that the creditors strengthen the oath of the truth that is not an indisputable receivable (Article 124 paragraph (3) Law No. 37 Of 2004), if the creditors have died, then curator can ask the heir who are entitled to explain under oath that with good faith that there was a receivable and not been paid (Article 124 paragraph (4) Law No. 37 Of 2004), against the receivable To produce an oath, while the oath has not been done because the creditors are not present or not represented, then the debt accepted with conditions, until the oath is done on the days specified (Article 126 paragraph (1) Law No. 37 Of 2004).

Each meeting verify made a transcript of proceeding signed by judges supervisors and the scribe of the successors and load on the list of recognized receivable. Recognition of the bills the bills get the force of law remains. 
After the meeting verify finished, curator made a report about the state of the bankruptcy estate and provide all the information requested by the Debtor and reports along with news of a meeting required verification provided by the Registrar and the Office of the curator.

Reconciliation is one of the chain value in the process of bankruptcy. Reconciliation in the bankruptcy process is often called by the term "akkord" (Dutch), is in English called with the term "Composition". Article 144 of Act No. 37 Of 2004 stated that the Debtor bankrupt reserves the right to offer a reconciliation to all the creditors. The purpose of reconciliation in the bankruptcy process is to determine the part of each man will be paid by the Debtor bankrupt or curator to liquidate their assets or not. ${ }^{7}$

The stages of the reconciliation process in a bankruptcy are the stage of submitted a reconciliation proposal and the announcement of the reconciliation plan, stage decision making reconciliation, stage of the homologation hearing and cassation against the homologation hearing. Submitted reconciliation proposal and the announcement by the way was placed in the Registrar of the Commercial Court done at the latest 8 (eight) days before the hearing the matching receivables (Article 145 paragraph (1) Law No. 37 of 2004). Reconciliation proposal discussed and taken the decision soon after the hearing of the matching receivables completed (Article 145 paragraph (1) Law No. 37 of 2004). The reconciliation proposal is accepted if it is approved in a creditor meeting by more than $1 / 2$ (one per two) the number of concurrent creditors present at the meeting and whose rights are recognized or temporarily recognized, representing at least 2/3 (two thirds) all recognized or acknowledged receivables recognized from the concurrent creditor or their proxies attending the meeting (Article 151 Law No. 37 of 2004).

If the reconciliation proposal received, and before the meeting is closed The Supervisory Judge sets the day of the Commercial Court hearing to ratify the reconciliation (homologation). If the Commercial Court refused to confirm the reconciliation, legal efforts is available for the parties that the objection to the rejection of the appeal to the Supreme Court. Bankruptcy ended after reconciliation ratified and legal approval remains, but if reconciliation was rejected, bankruptcy process immediately into insolvent situation.

Settings of the insolvent situation in the Law No. 37 Of 2004 arranged in Article 178 paragraph (1) as follows, if in meeting of matching receivables not offered reconciliation proposal, offered reconciliation proposal is not accepted or the legalization of reconciliation was

${ }^{7}$ Loc. cit. 
rejected based on the decision that has acquired the force of law remains, by the law assets of the debtor bankruptcy was in a state of insolvent.

Result of the insolvency or insolvent situation among others is the assets of debtor bankruptcy executed and distributed expect if there are specific considerations (for example business considerations) curator must start liquidate and selling all the assets of the debtor bankruptcy (Article 184 paragraph (1) Law No. 37 Of 2004).

The rehabilitation in the bankruptcy pleaded by the debtor or heir with the purpose to make debtor can do business activities and manage their assets back. The Petition submitted to the rehabilitation of the Commercial Court again check the corresponding bankruptcy, but not against all the bankruptcy can produce rehabilitation, as regulated in Article 125 Law No. 37 Of 2004 , i.e. when bankruptcy ended with a reconciliation, ended after the loan paid full, or bankruptcy are inflicted on property debtor.

As described in the explanation above the fulfillment of the debtor's debt through Bankruptcy Act which ended with the achievement of the reconciliation, does not cause the guarantor to be free from its obligation to guarantee debt repayment of debtor to creditor because based on Article 215 and 216 Law No. 37 of 2004, reconciliation achieved in bankruptcy does not always pay off debtor's debt to its creditors. Obligations of the guarantor with the achievement of reconciliation is arranged in terms of Article 165 paragraph (1) Law No. 37 Of 2004.

Remember that to achieve reconciliation on bankruptcy as a way of fulfilling debtor's debt to its creditors, in the form of distribution of the debtor's assets to its creditors, then debtor's assets is used to pay back the debt owing. Thus the achievement of reconciliation in the bankruptcy resulted in the guarantor cannot use privilege as it is regulated in Article 1830 Civil Code. Therefore the guarantor must pay the debtor's debt that borne which could not be paid with debtor's assets as in reconciliation that passed in the bankruptcy. If the guarantor do not pay yet then the guarantor privileged as the debtor, as regulated in Article 165 paragraph (1) Law No. 37 Of 2004 that is despite reconciliation, creditors still have rights against the guarantor and fellow debtor.

The debtor who fulfill the requirements as regulated in Article 2 paragraph (1) Law No. 37 Of 2004 can be pleaded for declaration of bankrupt. Article 2 paragraph (1) Law No. 37 Of 2004 set about the petition requirements for the declaration of bankrupt which the requirements include the bankruptcy statement regarding the number of creditors and the statement regarding the debt. Based on the terms, debtor that can be filed for bankruptcy is the debtor that have at 
least two of the creditors and the debtor's debt already maturing, can be billed and proofed simple.

Thus, if the guarantor is in bankruptcy of the debtor it bears, and bankruptcy ended because the legalization of reconciliation, the guarantor can be filed for bankruptcy if they fulfilled the provisions of Article 2 paragraph (1) Law No. 37 Of 2004. The party that can ask himself to be declared as bankrupt is the guarantor who reigned as the debtor if the guarantor did not carry out his duties as a result of the existence of the stipulation of Article 165 paragraph (1) or one or more of its creditors whether derived from other agreement guarantor or another creditor.

\section{Conclusion}

1. The Position of the Guarantor Against Debtor's Debt Fulfillment which ended with Reconciliation in Bankruptcy in Indonesia

The reconciliation that passed in bankruptcy does not always result in receivables of the creditors can be paid for. Based on the provisions of Article 165 paragraph (1) of Law No. 37 Of 2004 on Bankruptcy and Suspension of Obligation for Payment of Debts, the guarantor will still be obligated to pay off the debtor's debts that are borne.

2. Result of the Legalization of Reconciliation in the Bankruptcy Act Against the Submitted Petition for the Declaration of Bankrupt to Guarantor

Debt fulfillment through the Bankruptcy Act which ended with reconciliation can cause the guarantor to be debtor if not carry out his duties as regulated in Article 165 paragraph (1) of Law No. 37 Of 2004 on Bankruptcy and Suspension of Obligation for Payment of Debts, and the loss of privilege as set forth in the provisions of Article 1646 Civil Code, so that can be filed for bankruptcy if they fulfilled the requirements as regulated in Article 2 paragraph (1) of Law No. 37 Of 2004 on Bankruptcy and Suspension of Obligation for Payment of Debts. 


\section{References}

\section{Books}

Asikin, Zainal. 1994. Hukum Kepailitan dan Penundaan Pembayaran di Indonesia. Jakarta: PT Raja Grafindo Persada.

Fuady, Munir. 2005.Hukum Pailit dalam Teori dan Praktek. Bandung : Citra Aditya Bakti.

Ibrahim, Johnny. 2005. Teori dan Metodologi Penelitian Hukum Normatif. Malang: Banyumedia Publishing.

Jono. 2008. Hukum Kepailitan. Jakarta: Sinar Grafika.

Mulyadi, Kartini dan Gunawan Widjaya. 2005.Pedoman Menangani Perkara Kepailitan. Jakarta : Rajawali Pers.

Sastrawidjaya, ManS.. 2010. Hukum Kepailitan dan Penundaan Kewajiban Pembayaran Utang.Bandung: Alumni.

Shubhan, M. Hadi. 2008. Hukum Kepailitan : Prinsip, Norma, dan Praktik di Peradilan. Jakarta: Kencana.

Sidharta, Bernard Arief. 2009. Penelitian Hukum Normatif: Analisis Penelitian Filosofi dan Dogmatikal. Dalam Sulistyowati Irianto dan Sidharta. Eds. Metode Penelitian Hukum Konstelasi dan Refleksi. Jakarta : Yayasan Obor Indonesia.

Sjahdeini, Sutan Remy. 2010. Hukum Kepailitan Memahami Undang-Undang No. 37 Tahun 2004 Tentang Kepailitan. Jakarta : PT PustakaUtamaGrafiti.

Soemitro, Ronny Hanitijo. 1990. Metodologi Peneleitian Hukum dan Juri Metri. Jakarta : Ghalia Indonesia.

Susilowati, Etty. 2013. Hukum Kepailitandan Penundaan Pembayaran Utang. Semarang: Badan Penerbit UNDIP.

Wignjosoebroto, Sutandyo. 2003. Hukum: Paradigma, Metode dan Dinamika Masalahnya. Jakarta : Elsam \& Huma. 


\section{Regulations}

Kitab Undang-Undang Hukum Perdata (KUH Perdata)

Kitab Undang-Undang Hukum Dagang (KUH Dagang)

Undang-Undang No. 37 Tahun 2004 tentang Kepailitan dan Penundaan Kewajiban Pembayaran Utang

Undang-Undang No. 21 Tahun 2011 tentang Otoritas Jasa Keuangan (OJK) 